\title{
MIB-1, AgNOR AND DNA DISTRIBUTION PARAMETERS AND THEIR PROGNOSTIC VALUE IN NEUROENDOCRINE TUMOURS OF THE LUNG
}

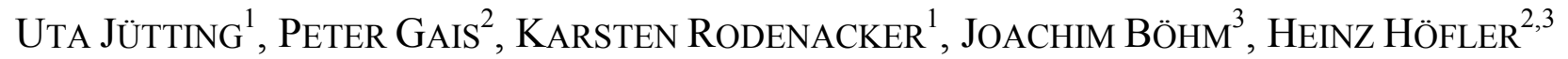 \\ ${ }^{1}$ Institute for Biomathematics and Biometry and ${ }^{2}$ Institute of Pathology, GSF-National Research Center for \\ Environment and Health, Neuherberg, ${ }^{3}$ Institute of Pathology, Technical University of Munich, Germany \\ (Accepted December 16, 1999)
}

\begin{abstract}
One of the most important questions in clinical routine is to find out patients with good or worse prognosis to apply an optimal therapy scheme for each patient. In this study 58 patients with different neuroendocrine tumours of the lung were investigated. Histological sections were prepared with different stainings (MIB-1, AgNOR, Feulgen). By means of high resolution image cytometry stereological parameters were derived which are indicators for proliferation, ploidy and kinetics of the tumours. Cox regression analysis was calculated to test the significance of the parameters with regard to prognosis. The best parameter was MIB-1 which can easily be applied as a clinical standard staining and measurement.
\end{abstract}

Keywords: AgNOR, carcinoid, DNA distribution, image analysis, MIB-1, neuroendocrine lung tumours, prognosis, small cell carcinoma.

\section{INTRODUCTION}

Lung cancer is in industrial countries the most frequent cause of death for men and women. The overall 5 -year survival rate is only about $15 \%$. One part of lung tumours are neuroendocrine tumours divided in subtypes with different malignant potential (benign or low-grade malignant tumours, called typical carcinoids (TC) and on the other side the high-grade malignant tumours, poorly differentiated of small (SCLC) or large cell type (LCLC). Between these tumour types, the welldifferentiated carcinoma with a lower grade of malignancy (WDNEC) take place (WHO, 1998). In clinical routine it is important to distinguish patients with better and worse prognosis. The aim of this study was to test the markers MIB-1, AgNOR and DNA distribution parameters, which are applied as different biological indicators of proliferation, ploidy and kinetics, with regard to the survival of patients and to the improvement of their therapy.

\section{MATERIAL AND METHODS}

In this study 32 cases of SCLC, 13 of WDNEC and 14 of TC with a follow-up time up to 7 years were collected. In Table 1 the complete clinical data set is shown. The tumour block was sliced into $4 \mu \mathrm{m}$ thick sections from paraffin embedded tissue from routine and were stained afterwards according to MIB-1 (Fig. 1)
(Böhm et al., 1996), AgNOR (Fig. 2) (Aubele et al., 1994a; Böhm et al., 1993) and Feulgen (Fig. 3) (Aubele et al., 1994b; Jütting et al., 1999).

\section{DATA ACQUISITION}

MIB-1. CAS 200 image analysis system, (63x objective, n.a. 0.8 , pixel size of $\left.0.32 \times 0.25 \mu \mathrm{m}^{2}\right), 2$ to 7 fields randomly selected within the tumour area. Two different filters $(500 \mathrm{~nm}$ and $620 \mathrm{~nm})$ were used for thresholding the nuclei area and the MIB-1 reactivity area, respectively.

AgNOR. SAMBA 2005 image analysis system, (Zeiss microscope, 40x objective, n.a. 0.65, optovar 1.6x, CCD-camera (Hamamatsu)). 4-7 fields randomly selected within the tumour area (100-150 cells/slide, digitized image $512 \times 512$ pixels, resulting pixel distance of $0.165 \mu \mathrm{m}$ ).

DNA. Zeiss Axiomat-microscope, (Bosch TVcamera (128x128 pixel), 100x objective (oil immersion, n.a. $1.3,548 \mathrm{~nm}$ filter, pixel distance $0.25 \mu \mathrm{m})$ ). 100 single tumour cell nuclei and 20 leukocytes (diploid peak) per slide, scanned in transmission with shading correction, recalculated to extinction (Haroske et al., 1994a, b). Thickness of the sections was measured by a laser scanning microscope at 5 locations. The mean thickness was $6.3 \mu \mathrm{m}(2.5-11 \mu \mathrm{m}$ range $)$. 
Table 1. Clinical data of 58 tumour patients of the lung separately for each tumour type.

32 SCLC:

sex

age

cell type

tumour size

lymph node involvement

metastasis

stage

therapy

survival time

\section{WDNEC:}

sex

age

tumour size $[\mathrm{cm}]$

lymph node involvement

therapy

survival time

\section{$13 T C:$}

sex

age

tumour size $[\mathrm{cm}]$

lymph node involvement

therapy

survival time
4 female, 28 male

$\mathrm{MV}=59.7$ years, range (38 to 77 years)

16 OAT, 16 ITM

$5 \mathrm{~T} 1,19 \mathrm{~T} 2,7 \mathrm{~T} 3,1 \mathrm{Tx}$

$8 \mathrm{~N} 0,8 \mathrm{~N} 1,11 \mathrm{~N} 2,2 \mathrm{~N} 3,3 \mathrm{Nx}$

$21 \mathrm{M} 0,10 \mathrm{M}+, 1 \mathrm{Mx}$

10 EXT, 22 LIM

$\mathrm{OP}$ and/or $\mathrm{R}$ and/or $\mathrm{CH}$

$\mathrm{MV}=25.3$ months, range (2 to 130 months)

29 patients deceased

7 female, 6 male

$\mathrm{MV}=51.5$ years, range (19 to 71 years)

$\mathrm{MV}=3.2 \mathrm{~cm}$, range $(0.9$ to $9 \mathrm{~cm})$

$7 \mathrm{~N} 0,6 \mathrm{~N}+$

$\mathrm{OP}$ and/or $\mathrm{R}$ and/or $\mathrm{CH}$

$\mathrm{MV}=51.7$ months, range (4 to 90 months)

5 patients deceased

5 female, 8 male

$\mathrm{MV}=56$ years, range (22 to 69 years)

$\mathrm{MV}=2.7 \mathrm{~cm}$, range $(1.0$ to $6 \mathrm{~cm})$

$10 \mathrm{~N} 0,3 \mathrm{~N}+$

$\mathrm{OP}$

$\mathrm{MV}=60.2$ months, range (12 to 101 months)

2 patient deceased

$\mathrm{LIM}=$ limited disease, $\mathrm{EXT}=$ extensive disease, $\mathrm{OP}=$ operation, $\mathrm{CH}=$ chemotherapy, $\mathrm{R}=$ radiotherapy, $\mathrm{OAT}=$ oat cell type, ITM = intermediate cell type

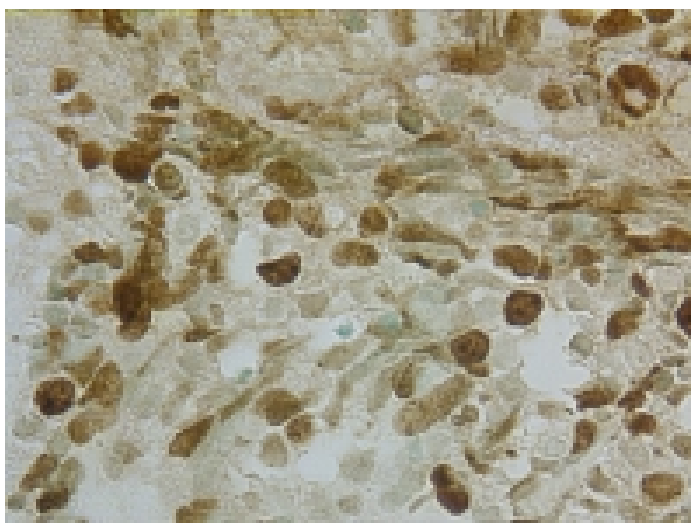

Fig. 1. MIB-1 stained nuclei.

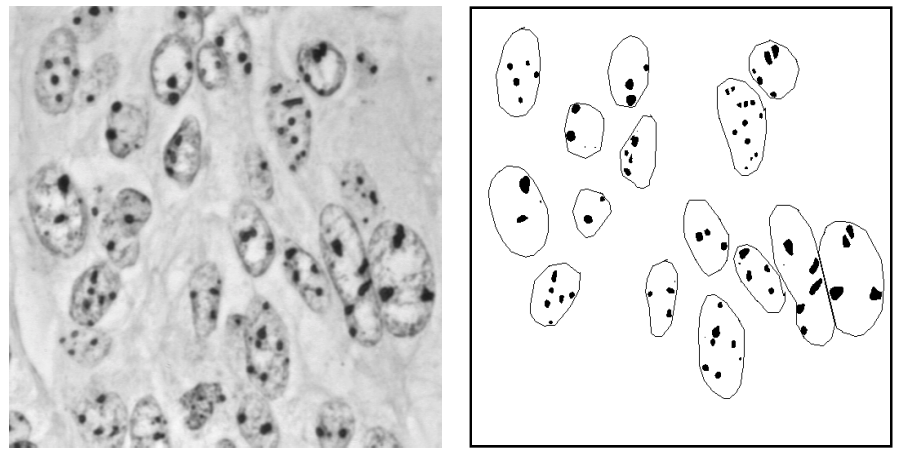

Fig. 2. AgNOR stained nuclei and segmentation mask. 

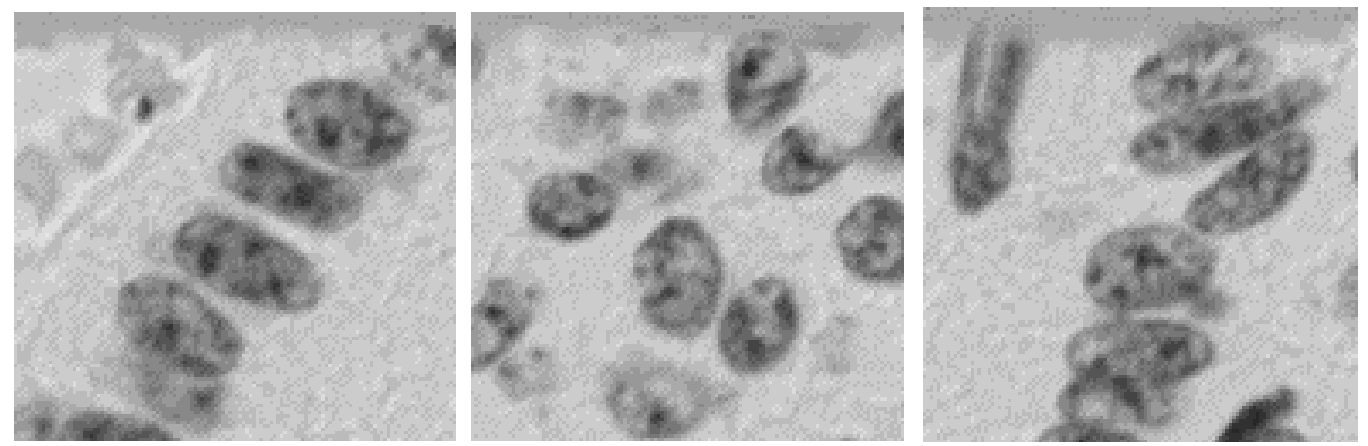

Fig. 3. Feulgen stained nuclei.

About 100 nuclei per case and staining were randomly gathered to extract stereological features as volume density, numerical volume density and different DNA parameters (Schenck et al., 1997).

\section{Stereological parameters}

$$
\mathrm{V}_{\mathrm{V}}(\mathrm{MIB}-1)=\frac{\sum \text { Area }_{\text {marked }}}{\sum \text { Area }_{\text {total }}}
$$

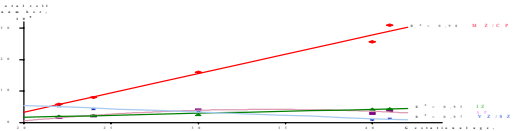

$$
\mathrm{N}_{\mathrm{V}}(\text { AgNOR })=\sqrt{\frac{\left(\sum \text { Number }_{\text {AgNORs }}\right)^{3}}{\left(\sum \text { Area }_{\text {nucleus }}\right)^{2} \sum \text { Area }_{\text {AgNORs }}}}
$$

For evaluating the 'real' DNA distribution from sections with different thickness following formulae have to be taken into account with the assumption that the nuclei are nearly round objects:

$$
\mathrm{fac}=\left\{\begin{aligned}
& \frac{1}{1-\frac{3 \mathrm{r}}{8 \mathrm{t}}} ; \text { if } \mathrm{r}<\mathrm{t} \\
& \frac{1}{\frac{3 \mathrm{t}}{4 \mathrm{r}}-\frac{1}{8}\left(\frac{\mathrm{t}}{\mathrm{r}}\right)^{3}} ; \text { if } \mathrm{r}>\mathrm{t} \\
& \mathrm{r}=\text { radius of nucleus } \\
& \mathrm{t}=\text { thickness of section }
\end{aligned}\right.
$$

IOD = integrated optical density (in extinction), normalization factor of lymphocytes $=1.6$ due to the underestimation of IOD of the dark and condensed lymphocytes, then

$$
\mathrm{DNA}_{\text {nucleus }}=\frac{\mathrm{IOD}_{\text {nucleus }} \mathrm{fac}}{\text { Mean( } \left.\mathrm{IOD}_{\text {lymphocytes }}\right)} 1.6
$$

From the DNA distribution the mean value, 5cexceeding rate, entropy, 2c-deviation index, value of stemline peak, proliferation status and the euploid/ aneuploid status (Ploidy) were calculated (Schenck et al., 1997). In Fig. 4 some typical DNA distributions for the different histological tumour types are shown.

Entropy: Entropy describes the information content and disorder of a histogram. Its lowest value is reached if all DNA-values are found in the same channel of the histogram. Its maximum will be reached, if all measured cells are equally distributed over all channels.

$$
\text { Entropy }=-\sum_{\mathrm{i}=1}^{\mathrm{N}} \mathrm{p}(\mathrm{i}) \operatorname{ld}(\mathrm{p}(\mathrm{i}))
$$

$2 c$ deviation index: In this histogram feature the cells are weighed with the square of their distance to the normal DNA content of $2 \mathrm{c}$.

$$
\begin{aligned}
2 \mathrm{cDI}= & \frac{1}{\mathrm{~N}} \sum_{\mathrm{i}=1}^{\mathrm{N}}\left(\mathrm{c}_{\mathrm{i}}-2 \mathrm{c}\right)^{2} \\
& \mathrm{c}_{\mathrm{i}}=\mathrm{c} \text {-value of nuclei } \mathrm{i}_{\mathrm{i}}
\end{aligned}
$$

\section{STATISTICS}

Stepwise Cox regression analysis was applied to search for features correlated with survival time (Lee, 1980). To demonstrate the results Kaplan-Meier curves for different strata are plotted. SAS and BMDP statistical packages were used. All statistical evaluations were done at $95 \%$ level. 


\section{RESULTS}

All calculated features were univariately tested by Cox regression analysis. Following features are significant:

$\begin{array}{ll}\mathrm{V}_{\mathrm{V}}(\mathrm{MIB}-1) & \mathrm{p}<0.0001 \\ \mathrm{~V}_{\mathrm{V}}(\text { AgNOR) } & \mathrm{p}=0.0123 \\ \text { DNA-Proliferation status } & \mathrm{p}=0.0090 \\ \text { Entropy } & \mathrm{p}=0.0003 \\ \text { 5c-Exceeding Rate } & \mathrm{p}=0.0046 \\ \text { DNA-Mean value } & \mathrm{p}=0.0073 \\ \text { Ploidy (eu/aneuploid) } & \mathrm{p}=0.0265\end{array}$

To demonstrate the results Kaplan-Meier survival curves for $\mathrm{V}_{\mathrm{V}}$ (MIB-1), $\mathrm{V}_{\mathrm{V}}$ (AgNOR) and proliferation status for different strata are plotted.

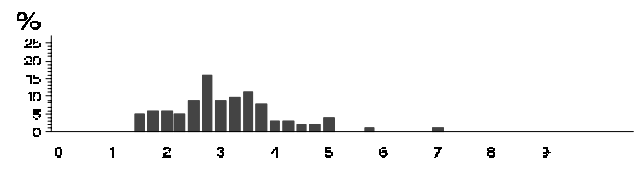

WDNEC

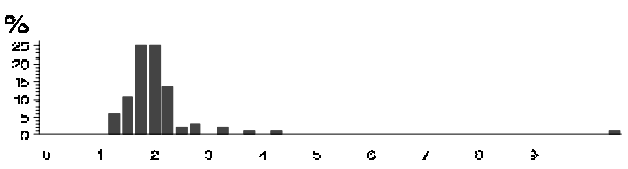

TC

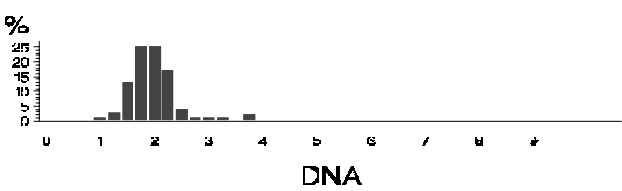

Fig. 4. Typical DNA distributions.

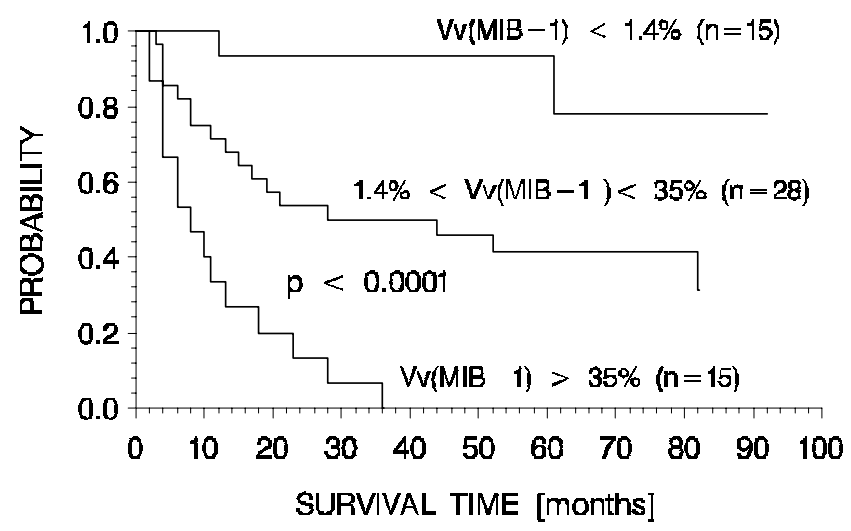

Fig. 5. Kaplan-Meier survival curves for $V_{V}(M I B-1)$ for 3 different strata.

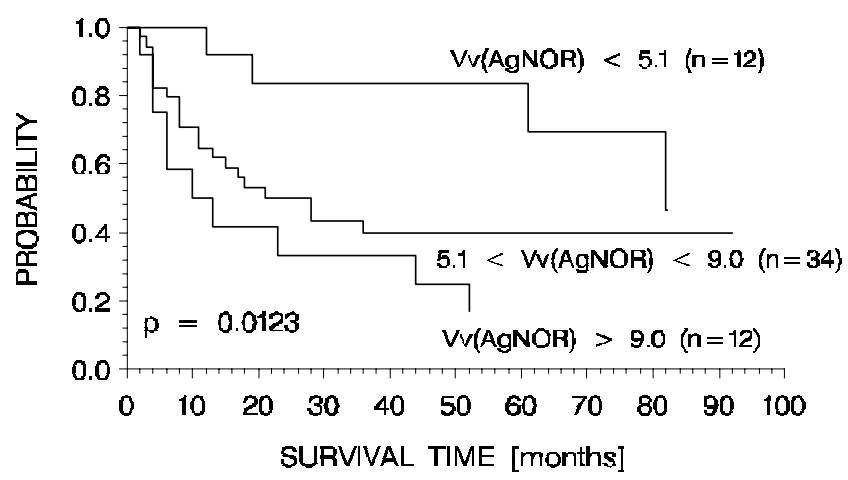

Fig. 6. Kaplan-Meier survival curves for $V_{V}(A g N O R)$ for 3 different strata.

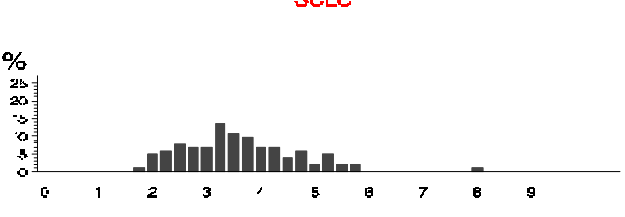

WDNEC
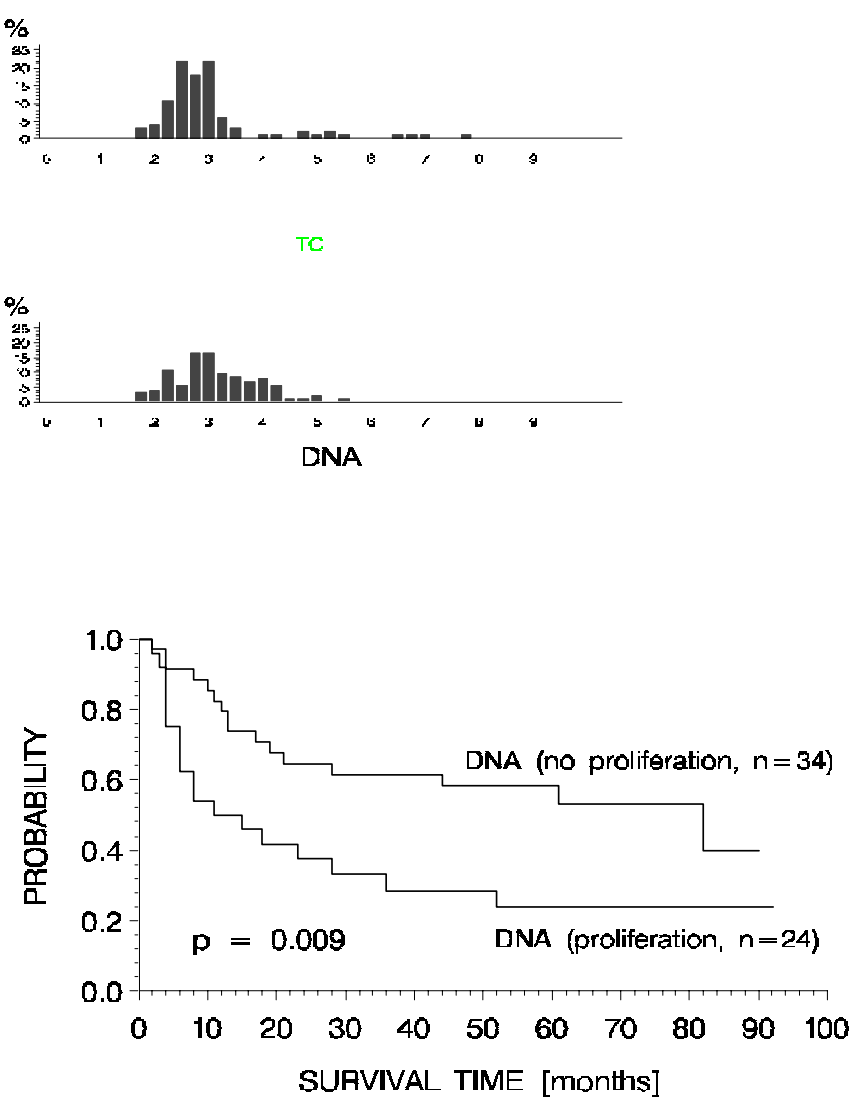

Fig. 7. Kaplan-Meier survival curves for proliferating and non proliferating DNA distributions. 


\section{SUMMARY}

DNA distribution parameters, $\mathrm{V}_{\mathrm{V}}(\mathrm{AgNOR})$ and $\mathrm{V}_{\mathrm{V}}$ (MIB-1) are significant to predict the survival of patients suffering of neuroendocrine tumours of the lung. To demonstrate the results Kaplan-Meier survival curves for three parameters are plotted for different strata. In clinical routine the application of MIB-1 staining is recommended due to its highest significance and quickest realisation. This investigation can be done before surgery even if only a biopsy exists and the histological diagnosis and the tumour staging (tumour size, lymph node involvement, metastasis) are not clear. According to the measured MIB-1 value an individual treatment scheme for each patient can be applied.

A preliminary report of some of the data (Jütting $e t$ al., 1999) was presented at the $X^{\text {th }}$ International Congress for Stereology, Melbourne, Australia, 1-4 November 1999.

\section{REFERENCES}

Aubele M, Auer G, Jütting U, Gais P (1994). Nucleolus organizer regions (AgNORs) in ductal mammary carcinoma. Their relation to clinical factors, DNA parameters and clinical course. In: M. Schmidt et al. eds. Prospects in Diagnosis and Treatment of Breast Cancer. Elsevier Science B.V, 47-56.

Aubele M, Burger G, Rodenacker K (1994). Problems concerning the quality of DNA measurements on Feulgen-stained imprints. A study of five fixation techniques. Analyt Quant Cytol Histol 16(3):226-32.
Böhm J, Kacic V, Gais P, Präuer HW, Höfler H (1993). Prognostic value of nucleolar organizer regions in neuroendocrine tumours of the lung. Histochemistry 99:85-90.

Böhm J, Koch S, Gais P, Aubele M, Jütting U, Präuer HW, Höfler H (1994). MIB-1 und AgNORs als Prognoseindikatoren bei neuroendokrinen Tumoren der Lunge. Verh Deutsch Ges Path 78:1-1.

Böhm J, Koch S, Gais P, Jütting U, Präuer HW, Höfler H (1996). Prognostic value of MIB 1 in neuroendocrine tumours of the lung. J Pathol 178:402-9.

Haroske G, Kunze KD, Dimmer V, Meyer W, Theissig F (1994a). Feasibility and limitations of cytometric DNA ploidy analysis procedures in tissue sections. Zentbl Pathol 139:407-17.

Haroske G, Meyer WD, Theissig F, Kunze KD (1994b). Increase of precision and accuracy of DNA cytometry by correcting diffraction and glare errors. Analyt Cell Pathol 9:1-12.

Jütting U, Gais P, Rodenacker K, Böhm J, Koch S, Präuer HW, Höfler H (1999). Diagnosis and prognosis of neuroendocrine tumours of the lung by means of high resolution image analysis. Analyt Cell Pathol 18:109-19.

Lee ET (1980). Statistical methods for survival data analysis. Belmont, CA: Lifetime Learning Publications, 298-337

Schenck U, Jütting U, Rodenacker K (1997). Modelling, definition and applications of histogram features based on DNA values weighed by SINE functions. Analyt Quant Cytol Histol 19:443-52.

World Health Organization (1998). The W.H.O. histologic typing of lung tumours. 2nd ed. Am J Clin Pathol 77:123-36. 